\title{
Colorectal Micropapillary Adenocarcinoma
}

National Cancer Institute

\section{Source}

National Cancer Institute. Colorectal Micropapillary Adenocarcinoma. NCI Thesaurus.

Code C96491.

A rare, invasive colorectal adenocarcinoma characterized by the presence of clusters of malignant glandular cells within stromal spaces. 